\title{
Restrukturyzacja polskiego przemysłu zbrojeniowego
}

W celu przeprowadzenia rozważań nad restrukturyzacją polskiego przemysłu zbrojeniowego należy najpierw przeanalizować stan wyjściowy.

\section{POLSKI PRZEMYSŁ OBRONNY W LATACH 1945-1990}

Struktura polskiego przemysłu zbrojeniowego wykrystalizowała się w latach 19511955, a wynikała z podziału zadań w ramach wspólnoty socjalistycznej. W tym okresie państwo zainwestowało w sektor obronny niespotykane dotąd środki finansowe. Zmalały one w latach 60., a ponownie wzrosły w 70 .

Duży wpływ miała dominująca rola ZSRR wśród krajów Rady Wzajemnej Pomocy Gospodarczej (RWPG), jak i Układu Warszawskiego (UW). To właśnie ten kraj wymusił pewną specjalizację wśród krajów bloku socjalistycznego. Aby żaden kraj satelicki nie stworzył samodzielnego przemysłu zbrojeniowego, ZSRR wprowadził pewien prosty, lecz skuteczny system. Można go nazwać polityką ograniczonego zaufania. Polegał on na tym, że każde państwo z bloku było tylko finalnym producentem danego wyrobu, natomiast produkcja podzespołów składających się na dany produkt była rozlokowana we wszystkich państwach wspólnoty socjalistycznej. Jako przykład można podać produkcję czołgu klasy „T”, którą w Polsce zajmował się Bumar Łabędy. Poszczególne zespoły były produkowane w następujących krajach:

- w Czechosłowacji produkowano: armatę, stabilizację, optykę, przekładnie pośrednią i siedzenia,

- w NRD: gąsienice, koła napędzające, systemy kierowania ogniem,

- w Rumunii: podgrzewacze,

- w Bułgarii: chłodnice i czujniki,

- na Węgrzech: zbiorniki i regulatory,

- w ZSRR: wykładziny obrony przeciwatomowej i łożyska.

Planowaniem całej produkcji zbrojeniowej w krajach socjalistycznych zajmował się Komitet Przemysłu Obronnego RWPG i Komitet Techniczny Sztabu Układu Warszawskiego. Instytucje te planowały wprowadzanie do produkcji, a także na wyposażenie armii Układu nowego uzbrojenia, jak również ustalanie wieloletniego zapotrzebowania i wielkości wzajemnych dostaw wyposażenia wojskowego. Właściwie organy te mogły łatwo wpływać na 
to, co działo się z przemysłem zbrojeniowym w państwach członkowskich. Oczywiście także i tu dominującą rolę ogrywał ZSRR. Również dzięki tym, wysoce scentralizowanym, mechanizmom ZSRR przyczyniał się do coraz większego uzależnienia państw satelickich od siebie. Największe uzależnienie od ZSRR wystąpiło w takich dziedzinach, jak technologie i licencje (otrzymywane od ZSRR), rynki zbytu, zaplecze naukowo-badawcze i zaopatrzenie w specjalistyczne materiały i podzespoły. Jak można zauważyć, były to niezwykle ważne elementy niezbędne do stworzenia silnego i niezależnego przemysłu obronnego.

Mimo ścisłej kontroli ze strony ZSRR, polski przemysł obronny rozwijał się. W szczytowym okresie swojego rozwoju, czyli w latach 80., obejmował on:

- 10 ośrodków badawczo-rozwojowych,

- 82 przedsiębiorstwa mające status przedsiębiorstwa przemysłu obronnego (PPO),

- około 600 kooperantów produkcji „S”,

- około 3400 przedsiębiorstw realizujących zadania na czas zagrożenia i wojny w zakresie gospodarczo-obronnym.

W ramach specjalizacji w polskim przemyśle zbrojeniowym stworzono duże możliwości produkcyjne. W ciągu roku Polska była w stanie wyprodukować (w szczytowym momencie):

- do 300 czołgów,

- około 160 samolotów szkolno-bojowych i transportowych,

- około 350 śmigłowców,

- około 1300 silników do śmigłowców,

- do 600 ciągników artyleryjskich,

- do 600 transporterów opancerzonych, gąsienicowych,

- do 700 rakiet przeciwlotniczych, przeciwpancernych i lotniczych,

- około 250 dział samobieżnych,

- do 9000 radiostacji i urządzeń radiolokacyjnych różnych typów,

- około 400 systemów kierowania ogniem czołgów,

- kilkanaście asortymentów broni strzeleckiej indywidualnej i zespołowej,

- kilkadziesiąt rodzajów amunicji strzeleckiej, artyleryjskiej i lotniczej.

Jednak, jak już wspomniano wcześniej, nie znaczy to, że Polska była to wszystko W stanie wyprodukować samodzielnie. W tych czasach eksport polskiego sprzętu „S” (czyli wyrobów zbrojeniówki), skierowany był głownie do krajów bloku wschodniego i zaprzyjaźnionych. Oczywiście zbyt na całą, lub prawie całą, produkcję był zapewniony. Trzeba przy tym nadmienić, że Polska miała ograniczone możliwości w kwestii doboru odbiorców dla swojej produkcji. Było to m.in. spowodowane faktem, że większość uzbrojenia była produkowana na licencji radzieckiej, a licencjodawca ograniczał liczbę krajów, do których dany produkt mógł być sprzedawany. Jednak te ograniczenia miały również pozytywny wpływ na polską zbrojeniówkę, gdyż wymusiły, dla obejścia wspomnianych ograniczeń, opracowywanie rodzimych konstrukcji.

Łącznie w okresie 1945-1989 polski przemysł zbrojeniowy dostarczył dla rodzimej armii, a także na eksport ponad 9000 czołgów, około 4000 stacji radiolokacyjnych, a także pokrył praktycznie całe zapotrzebowanie polskiej armii na różnego rodzaju amunicję. Oprócz tego adaptowano dla przemysłu szereg nowych technologii (przy wdrożeniu produkcji czołgów T-72 zastosowano ich około 160). Niestety mimo to powiększała się luka technologiczna pomiędzy Polską a krajami zachodnimi. Ponieważ w ofercie brakowało produktów 
nowoczesnych, to jeszcze w latach 80. krag nabywców ograniczał się do krajów Układu Warszawskiego i krajów rozwijających się.

Trudno się więc dziwić, że według danych Sztokholmskiego Instytutu Badań nad Pokojem (SIPRI) Polska, która w latach 80. znajdowała się w czołówce państw eksportujących uzbrojenie, w 1992 roku nie znalazła się już w pierwszej piętnastce. W 1985 roku, według źródeł amerykańskich, Polska zajmowała 5 miejsce pod względem wartości eksport broni [ACDA 1987], a w latach 1988-1989 - 7 miejsce [wg SIPRI]. W ówczesnych czasach eksport posiadał szczególne znaczenie dla tej gałęzi przemysłu, jako czynnik racjonalizujący struktury produkcyjne i podwyższający efektywność wykorzystania istniejących zdolności wytwórczych. Niestety pod koniec lat 80 . pojawiły się już zwiastuny nadchodzącego kryzysu w polskiej produkcji specjalnej. Świadczyło o tym choćby to, że do końca tej dekady nie wdrożono do produkcji żadnych nowych, znaczących wyrobów bojowych (tylko niektóre wyroby pomocnicze). Fakt, że takie wdrożenie wymaga znacznych nakładów finansowych sprawił, że sytuacja ta rzutowała na lata 90. i atrakcyjność eksportowa polskich wyrobów bardzo szybko zdystansowała się od ofert zachodnich producentów.

W szczytowym momencie rozbudowy polskiej zbrojeniówki, czyli w roku 1987, było w niej zatrudnionych 250 tysięcy osób. W następnych latach, liczba zatrudnionych w przemyśle obronnym systematycznie malała. W kolejnych latach wynosiła ona:

$$
\begin{aligned}
& -1997-68000 \\
& -1998-56500 \\
& -1999-51500 \\
& -2000-45500 \\
& -2001-34500^{*}
\end{aligned}
$$

Przemiany gospodarczo-ustrojowe zapoczątkowane w 1989 roku silnie odbiły się na polskiej zbrojeniówce. Środki finansowe przeznaczone na wspieranie zbrojeniówki musiały zostać przerzucone na inne potrzeby państwa. Silne więzy kooperacyjne ze zbrojeniówkami innych krajów dawnego bloku socjalistycznego, tak istotne dla produkowanych w Polsce produktów, zostały zerwane. Dawni współpracownicy stali się konkurentami na kurczącym się rynku uzbrojenia. Zakłady przestały mieć zagwarantowany zbyt dla swojej produkcji, dotacje państwa były coraz bardziej ograniczane. Ponieważ nastąpił gwałtowny spadek zamówień na sprzęt wojskowy zarówno ze strony odbiorców zagranicznych, jak i rodzimego MON, zaczęła więc narastać dysproporcja pomiędzy możliwościami produkcyjnymi a popytem na sprzęt wojskowy, w wyniku czego coraz większa część potencjału wytwórczego zbrojeniówki pozostawała niewykorzystana. W związku z problemami sektora zbrojeniowego postanowiono go zrestrukturyzować.

Do 1990 roku wszystkie polskie firmy produkujące i sprzedające sprzęt „S” były w 100\% państwowe. Istniał w nich przerost zatrudnienia, a także były w dużym stopniu wspierane przez rząd. Zasady finansowania zadań spełnianych przez zbrojeniówkę wyglądały następująco:

- dostawy uzbrojenia i sprzętu wojskowego finansowane były przez odbiorców, w niektórych przypadkach eksport (głównie do ZSRR) był dofinansowany przez budżet;

- prace badawczo rozwojowe $(B+R)$ finansowane były przez budżet i specjalnie tworzone fundusze $\mathrm{B}+\mathrm{R}$;

* Należy do tych danych podchodzić z pewną rezerwą, gdyż obecnie jest wiele firm prywatnych, które produkują towary na potrzeby wojska, takie jak buty, mundury, szeroko rozumianą elektronikę itp. Mogą one jednak być użyte do pewnego porównania, gdyż dotyczą firm mających podobne spektrum produkcji, co te, których dotyczą dane za rok 1987. 
- inwestycje specjalne finansowane były ze środków własnych przedsiębiorstw, kredytów bankowych i w znacznym stopniu z dotacji budżetowych.

W roku 1990 to się skończyło. W 2002 roku zgodnie z ustawą do przemysłowego potencjału obronnego należało 38 spółek produkcyjnych prowadzących działalność na potrzeby bezpieczeństwa państwa, 3 spółki realizujące obrót „S”, 12 przedsiębiorstw państwowych prowadzących działalność remontowo-produkcyjną na potrzeby bezpieczeństwa i obronności państwa, 10 jednostek badawczo-rozwojowych. Profil produkcyjny 38 spółek produkcyjnych był następujący:

-8 - przemysł lotniczy,

-7 - przemysł chemiczny i gumowy,

- 9 - przemysł elektroniczny i precyzyjny,

-5 - przemysł maszynowy,

-3 - przemysł stoczniowy,

- 6 - producenci broni, amunicji i materiałów wybuchowych [Kułakowski 2004].

Aby uzdrowić sytuację w przemyśle obronnym (w jego państwowej części) opracowano kilka programów restrukturyzacji:

- Studium sektorowe i ogólne założenia pierwszego etapu restrukturyzacji przemysłu obronnego - Proxy Sp. z o.o. - 1991 r.,

- Projekt przebudowy sektora zbrojeniowego - Ministerstwo Przemysłu i Handlu (MPIH), przełom roku 1991 i 1992,

- Program konsolidacji i oddłużenia przedsiębiorstw przemysłu obronnego - PIH 1993 ,

- Program restrukturyzacji sektora przemysłu obronnego i lotniczego na lata 1996-2010 - Rada Ministrów (RM), 1996,

- Program restrukturyzacji przemysłu obronnego i wsparcia w zakresie modernizacji technicznej Sił Zbrojnych RP - RM, 1999,

- Strategia przekształceń strukturalnych przemysłowego potencjału obronnego w latach 2002-2005 - RM, 2002.

\section{Program Proxy}

Był to pierwszy program restrukturyzacji. Program ten wskazywał następujące czynniki, które musiały być spełnione, aby restrukturyzacja zakończyła się sukcesem:

- precyzyjne zdefiniowanie funkcji Sił Zbrojnych RP, rządu oraz przedsiębiorstw przemysłu obronnego na tle szeroko rozumianej polityki obronnej,

- zagwarantowanie środków finansowych na bieżącą realizację zadań nałożonych na Siły Zbrojne RP, których niewykonanie mogłoby zagrozić programowi restrukturyzacji (zmniejszanie zakupów spowoduje ograniczenie dopływu pieniędzy do przedsiębiorstw),

- zagwarantowanie środków finansowych na realizację programów restrukturyzacyjnych przewidzianych w biznesplanach dla poszczególnych przedsiębiorstw,

- zagwarantowanie środków finansowych na finansowanie pomostowe dla przedsiębiorstw objętych restrukturyzacją.

W tym czasie, cechy przedsiębiorstw polskiej zbrojeniówki, wg Proxy, były następujące:

- generalnie dobre wyposażenie techniczne oraz wysokie standardy technologiczne; jednakże rażą niekiedy sztucznie niezamknięte ciągi produkcyjne, 
- w większości brak odpowiednich struktur marketingowych oraz fachowej kadry; w niektórych przypadkach prowadzone są próby badań rynkowych (np. PCO, Radwar, Łabędy); obrót specjalny jest dokonywany w wąskim zakresie wyznaczonym ramami nadawanych koncesji; głównymi pośrednikami są centrale handlu zagranicznego: PHZ Cenzin, Cenrex, PHZ Pezetel, PHZ Bumar,

- systemy informowania kierownictwa - z wyjątkiem danych o produkcji - nie są rozwinięte; przedsiębiorstwa mają trudności z wydzieleniem kosztów produkcji specjalnej i cywilnej,

- zróżnicowane warunki finansowe; generalnie wszystkie przedsiębiorstwa wykazują spadek zysków (co nie jest dziwne w obliczu malejących zakupów broni dokonywanych w Polsce, jak również z problemami ze zbytem za granica) i pogorszenie cashflow $\mathrm{w}$ porównaniu do roku poprzedniego,

- większość przedsiębiorstw rozpoczęła porządkowanie problemów prawnych, w szczególności praw do nieruchomości; szczególną cechą tego sektora jest względnie jasna sytuacja majątku związanego z produkcją (ze względu na przedwojenną własność państwową lub poniemiecką) i bardzo niejasny status obiektów nieprodukcyjnych.

W raporcie przedstawiono 3 wersje restrukturyzacji: wersje „0", wersje „minimum” i wersje ,kompleksową”. Wersja „0” zakładała brak jakiejkolwiek ingerencji w sektor obronny. Pozwoliłaby ona na uniknięcie niektórych kosztów, takich jak koszty finansowania pomostowego i koszty wdrażania programu restrukturyzacji. W wypadku przyjęcia takiego rozwiązania, kryzys w sektorze obronnym dalej by się pogłębiał. Problem dalej pozostałby, a jedynie zostałby przesunięty w czasie. Dodatkowo w dalszym ciagu wzrastałoby zadłużenie zbrojeniówki przy jednoczesnym kurczeniu się rynków zbytu. W wersji tej, w ciągu pierwszych dziewięciu miesięcy 1992 roku, łączne straty przedsiębiorstw zbrojeniowych miałyby wzrosnąć w stosunku do analogicznego okresu 1991 roku.

W wersji „minimum” podzielono przedsiębiorstwa na trzy grupy: grupę A - przedsiębiorstwa, których stopa zysku wynosiła ponad 3\%; grupę B - przedsiębiorstwa, których strata w zasadzie nie przekraczała $5 \%$, a poziom kosztów sprzedaży własnej - 85\%; grupe C, w której znalazła się reszta przedsiębiorstw. W wersji tej założono, że przedsiębiorstwa z grupy A są zdolne do właściwej reakcji na zmiany rynkowe, a tym samym do przeprowadzenia restrukturyzacji własnymi siłami. Firmy te miałyby same opracować własne programy restrukturyzacji. Dla firm z grupy B przewidziano kompleksową restrukturyzację, której istotą miałoby być rozdzielenie, w miarę możliwości, produkcji cywilnej od specjalnej, a także propozycja korzystnych, z punktu widzenia przedsiębiorstwa, fuzji przy uwzględnieniu wymagań związanych z ochroną technologii wojskowych. W grupie tej należałoby zlikwidować około $30 \%$ mocy produkcyjnych. Wersja ta przewidywała uruchomienie produkcji nowych wyrobów gwarantujących zysk, a także promocję już produkowanych wyrobów na nowych segmentach rynku. Oczywiście przeprowadzenie zmian wiązałoby się z pewnymi kosztami. Dla firm z grupy C przewidziano jedynie restrukturyzację pod względem ochrony koniecznej produkcji obronnej. W wersji „minimum” przewidywano, że w 1992 roku przedsiębiorstwa (łącznie) osiagną zyski.

Natomiast wersja „kompleksowa” był przewidziana na dłuższy czas, nie wykluczała jednak osiagania pozytywnych wyników przez przedsiębiorstwa także w krótkim czasie. Jej celem było utworzenie dużych holdingów zbrojeniowych. Miały to być następujące holdingi:

$$
\begin{aligned}
& \text { - Mesko, } \\
& \text { - Łabędy, } \\
& \text { - lotniczy. }
\end{aligned}
$$


Ich cechy miały być następujące:

- prowadzenie produkcji i sprzedaży wyrobów cywilnych i wojskowych,

- prawo do eksportu swoich wyrobów, w tym prawo do przystępowania do spółek handlu zagranicznego,

- koncentracja kapitału umożliwiająca podjęcie wymaganych prac badawczych dla zwiększenia konkurencyjności swoich wyrobów,

- dopuszczenie powiązań kapitałowych z zagranicznymi partnerami.

W pierwszym etapie restrukturyzacji nie przewidywano likwidacji zatrudnienia ani likwidacji części majątku przedsiębiorstw. Na tym etapie planowano wydzielenie z dotychczasowych przedsiębiorstw spółek-córek mających wchodzić w skład przyszłych holdingów. Proces przekształcania przedsiębiorstw miał się rozpocząc po zaproponowaniu struktury holdingów. W tej wersji proces restrukturyzacji miało zakończyć powołanie odrębnych rad nadzorczych dla każdej spółki-córki z osobna. Oceniano, że takie rozwiązanie pokaże swoją przewagę nad wariantem „minimum” dopiero, po co najmniej roku.

W wersji „kompleksowej”, przedsiębiorstwa miały (łącznie) osiagnąć zyski już w 1992 roku. Ich wielkość miałaby być porównywalna do wersji „minimum”, jednak w następnych latach większe zyski miałyby być osiągane w wersji „kompleksowej”. Ze względu na brak woli politycznej, a przede wszystkim z powodu niezapewnienia odpowiedniego finansowania nie wprowadzono zmian, o których mowa w raporcie. Z przedsięwzięć zawartych w „Projekcie przebudowy sektora zbrojeniowego” i w „Programie komercjalizacji i oddłużenia przedsiębiorstw przemysłu obronnego", zmierzających do złagodzenia sytuacji przedsiębiorstw sektora, zapoczątkowano procesy konwersji i koncentracji produkcji „S”, uregulowano sposób wypłat z tytułu Programu Mobilizacji Gospodarki (PMG), dokonano oddłużenia, skompensowano straty poniesione przez przedsiębiorstwa z tytułu embarga na dostawy sprzętu „S” i doprowadzono do powstania wewnętrznych programów restrukturyzacyjnych (Raport... 1991).

\section{PROGRAM RESTRUKTURYZACJI SEKTORA PRZEMYSŁU OBRONNEGO I LOTNICZEGO} NA LATA 1996-2010

W związku z fiaskiem poprzednich programów restrukturyzacji zbrojeniówki, Rada Ministrów przygotowała kolejny program. Jego celami było:

- określenie docelowego modelu sektora zbrojeniowego skorelowanego z Systemem Obronnym Państwa (SOP),

- wskazanie optymalnych, pod względem potrzeb i możliwości, kierunków przebudowy przemysłu obronnego, uwzględniających uwarunkowania wewnętrzne (zwłaszcza wielkość zamówień, na które mogą liczyć zakłady), a także sytuację na międzynarodowym rynku broni,

- opracowanie strategii wdrażania przyjętego modelu organizacji przemysłu obronnego ze szczególnym uwzględnieniem długofalowego programu modernizacji sił zbrojnych.

Program ten podzielono na dwa podprogramy: krótkookresowy (1996-1998) i długookresowy (do 2010).

Program krótkookresowy przewidywał:

- koncentrację dotychczasowej produkcji „S”, którą Siły Zbrojne były zainteresowane do 2005 r. i która mogła być przedmiotem eksportu, 
- konwersję produkcji „S” na „C” rozumianą jako spadek wskaźnika S/C w ujęciu wartościowym,

- utrzymywanie $\mathrm{w}$ gotowości zdolności produkcyjnych wyrobów „S” niezbędnych w okresie zagrożenia i potrzymanie systemu CPMG,

- przekształcenia przedsiębiorstw zmierzające do ujawnienia centrów zysków i centrów kosztów,

- realizację inwestycji odtworzeniowych,

- realizację programów oddłużeniowych,

- rozwijanie eksportu i programów marketingowych,

- usprawnienie zaplecza badawczo-rozwojowego i wdrożeń w zakresie modernizacji wyrobów i podnoszenia ich jakości,

- realizację wewnętrznych programów restrukturyzacji przez przedsiębiorstwa sektora.

Źródłami jego finansowania miały być:

- specjalny fundusz (Fundusz Restrukturyzacji Przemysłu Obronnego i Lotniczego - FRPOiL),

- środki własne przedsiębiorstw,

- fundusz PMG,

- kredyty bankowe,

- środki Komitetu Badań Naukowych,

- środki na inwestycje centralne,

- zagraniczne fundusze pomocowe (EFSAL, PHARE).

Natomiast składowymi podprogramu długookresowego miały być:

- Strategiczne Programy Rządowe (SPR),

- konsorcja programowe tworzone dla realizacji SPR,

- wprowadzenie zmian w organizacji sektora zmierzających w kierunku budowy struktur holdingowych,

- system obrotu z retencją (SOR), polegający na gromadzeniu niezbędnych - minimalnych zapasów wyrobów „S”, traktowanych jednocześnie jako zapasy strategiczne i jako zabezpieczenie realizacji doraźnych kontraktów eksportowych,

- centra akwizycji wyrobów „S” w warunkach eksploatacji wojskowej,

- Fundusz Inwestycyjny Narodowego Przemysłu Obronnego - FINPO, tworzony na podobieństwo Narodowych Funduszy Inwestycyjnych - NFI w celu przeprowadzenia przemieszczenia i konwersji asortymentowych, a także sfinansowania niezbędnych inwestycji.

Ta część programu miała być finansowana poprzez:

- specjalne fundusze (początkowo FRPOiL, a docelowo FINPO),

- kredyty bankowe,

- środki przedsiębiorstw sektora,

- kapitał przedsiębiorstw zagranicznych wchodzących w kooperację przy realizacji SPR.

Programu jednak nie udało się zrealizować. Według Najwyższej Izby Kontroli (NIK), przede wszystkim spowodowane to było problemami z finansowaniem. Nie wdrożono instrumentu w postaci FRPOiL. Negatywny wpływ miała też przeprowadzona reforma administracji centralnej. Podczas niej rozdzielono kompetencje w stosunku do przemysłu obronnego, które do tej pory znajdowały się w gestii Ministerstwa Przemysłu i Handlu. Po reformie za politykę wobec sektora odpowiadało Ministerstwo Gospodarki, a nadzór właścicielski sprawowało Ministerstwo Skarbu Państwa. 
Problemem było też to, że podczas opracowywania programu, nie znana była do końca koncepcja technicznej modernizacji Sił Zbrojnych RP. Nie sprawdziła się również prognoza trwałej poprawy sytuacji ekonomicznej w wyniku prowadzonych procedur oddłużeniowych, ani założenie znaczącego wzrostu zamówień MON. Unowocześnianie wyrobów „S” odbywało się praktycznie wyłącznie na podstawie środków na badania i rozwój pochodzących z MON i KBN. Wartość tych środków znacząco spadła między innymi w obliczu załamania się strategicznych programów rządowych, jak „Śmigłowiec wielozadaniowy S-1W HUZAR”. W tym czasie finansowany był jedynie jeden strategiczny program rządowy dla obronności kraju, tj. program LOARA. Koncentracja produkcji odbywała się w ramach reorganizacji wewnętrznej spółek jak i między spółkami. Nie został stworzony odrębny mechanizm restrukturyzacji zadłużenia dla spółek przemysłowego potencjału obronnego (ppo). Wnioski w tej sprawie były wnoszone indywidualne przez spółki na mocy powszechnie obowiązującego prawa. Ze względu na ograniczenia wydatków z budżetu na zakupy uzbrojenia i sprzętu przez MON nie wzrosły przychody z tytułu sprzedaży dla tego odbiorcy. Dekoniunktura na rynkach światowych oraz stosunkowo wąska oferta konkurencyjnych wyrobów polskiego przemysłu obronnego na rynkach światowych nie stworzyła warunków do poprawy sytuacji spółek. Nie utworzono także wtedy planowanych holdingów [Informacja... 2004].

\section{PROGRAM RESTRUKTURYZACJI PRZEMYSŁU OBRONNEGO I WSPARCIA} W ZAKRESIE MODERNIZACJI TECHNICZNEJ SIŁ ZBROJNYCH

Program ten składał się z trzech części. W pierwszej był opis stanu obecnego i diagnoza stanu polskiego przemysłu obronnego. Druga poświęcona była przemysłowi obronnemu w innych krajach, a trzecia to materiały uzupełniające. Ostateczna wersja programu uwzględniała takie zalecenia Rady Ministrów, jak:

- rezygnacja z konsolidacji niektórych spółek przemysłowego potencjału obronnego w holdingi,

- prowadzenie prywatyzacji w powiązaniu z zakupami uzbrojenia i sprzętu wojskowego oraz transakcjami kompensacyjnymi (czyli offsetem),

- realizacja procesów prywatyzacyjnych przez Ministra Skarbu Państwa według kierunków określonych przez zespół powołany decyzją Prezesa Rady Ministrów.

Na podstawie tego programu miały być opracowane ustawy o restrukturyzacji przemysłowego potencjału obronnego i wsparcia w zakresie modernizacji technicznej Sił Zbrojnych RP i o transakcjach kompensacyjnych. Najważniejszym celem tego programu było zapewnienie wzrostu konkurencyjności polskiej zbrojeniówki na rynku światowym. Przedstawiono w nim koncepcję działań, które należało podjąć i wskazano liczne instrumenty i propozycje przedsięwzięć, które w pewnej perspektywie miały się przyczynić do wzrostu konkurencyjności branży.

Cele szczegółowe dotyczyły natomiast restrukturyzacji i prywatyzacji przedsiębiorstw, nowego systemu promocji i finansowania eksportu, utrzymywania mocy produkcyjnych i remontowych na potrzeby Centralnego Planu Mobilizacji Gospodarki (CPMG). W części restrukturyzacji, za którą odpowiadały Ministerstwo Finansów, Ministerstwo Gospodarki i Ministerstwo Pracy i Polityki Społecznej, zakładano pomoc w restrukturyzacji finansowej, majątku i zatrudnienia, w konsolidacji produkcji i konwersji produkcji „S” na „C” (cywilną). 
Jeśli chodzi o konsolidację produkcji to po prostu produkcja „S” miała się odbywać w mniejszej, niż dotychczas, liczbie zakładów.

W sprawozdaniu z realizacji (wg stanu na 31 grudnia 2001) ustawy o wspieraniu restrukturyzacji przemysłowego potencjału obronnego i modernizacji technicznej Sił Zbrojnych, Departament Przemysłowego Systemu Obronnego Ministerstwa Gospodarki stwierdził, że restrukturyzacja zobowiązań nie przyniosła oczekiwanych efektów. Jedynym obszarem, w którym konsekwentnie realizowano procesy dostosowawcze była restrukturyzacja (czyli redukcja) zatrudnienia i wspierający ją system rekompensat.

W odniesieniu do prywatyzacji przedsiębiorstw, którą realizowało MSP przewidywano przeprowadzenie maksymalnej prywatyzacji z jednoczesnym zachowaniem kontroli w przedsiębiorstwach strategicznych, zachowanie najważniejszych więzi kooperacyjnych. Należało przy tym uwzględnić specyfikę przemysłu obronnego.

Niestety z planowanej prywatyzacji 26 spółek przeprowadzono zaledwie dwie. Porażką zakończyło się również stworzenie nowego systemu finansowania promocji eksportu. Główną przyczyną był brak porozumienia pomiędzy MSZ, MON i MG, przede wszystkim w kwestii jego finansowania. Nie powołano także Konsorcjum Finansowania Eksportu, które miało wspierać finansowanie produkcji eksportowej na korzystnych warunkach [Informacja... 2004].

\section{STRATEGIA PRZEKSZTAŁCEŃ PRZEMYSŁOWEGO POTENCJAŁU OBRONNEGO W LATACH 2002-2005}

Celem kolejnego programu było określenie działań dla stworzenia efektywnych mechanizmów ekonomiczno-finansowych oraz zmian przepisów prawnych, które pozwolą na rewitalizację i rozwój przemysłowego potencjału obronnego, szczególnie w kontekście udziału polskiego przemysłu w procesie unowocześnienia Sił Zbrojnych, zgodnie z Programem przebudowy i modernizacji technicznej Sił Zbrojnych RP w latach 2001-2006 i realizacji umów offsetowych związanych z tym procesem.

Cele cząstkowe były następujące:

- wywiązanie się ze zobowiązań sojuszniczych w sferze wyposażenia technicznego Sił Zbrojnych, jakie podjęła Polska przystępując do NATO,

- dostosowanie potencjału produkcyjnego do potrzeb Sił Zbrojnych RP, jego skonsolidowanie kapitałowe przy równoczesnym nadaniu produkcji „S” charakteru proeksportowego,

- zachowanie istniejącego potencjału intelektualnego i naukowo-technicznego,

- stymulowanie postępu technicznego i technologicznego,

- osiagnięcie stabilizacji ekonomicznej przedsiębiorstw ppo,

- realizacja planowanych dużych kontraktów eksportowych i offsetowych,

- unowocześnianie produkcji uzbrojenia i sprzętu wojskowego, zgodnie z oczekiwaniami Sił Zbrojnych RP, a także dla sprostania konkurencji na światowym rynku broni,

- przeciwdziałanie narastającemu bezrobociu w regionach, na terenie których zlokalizowane są spółki ppo. 
Docelowo realizacja strategii miała na celu stworzenie efektywnego ppo, dysponującego odpowiednim zapleczem kapitałowym i technologicznym, który będzie:

- mógł zabezpieczyć potrzeby Sił Zbrojnych RP w zakresie nowoczesnego uzbrojenia i sprzętu wojskowego,

- miał szanse na unowocześnianie produkcji, co w efekcie ma doprowadzić do zdobycia nowych kontraktów eksportowych,

- gotowy do realizacji projektów offsetowych.

Postanowiono stworzyć grupy kapitałowe, które miały się składać ze spółki dominującej (konsolidującej), spółki organizującej marketing i sprzedaż oraz ze spółek produkcyjnych (zależnych). Powstały dwie grupy: pancerno-amunicyjno-rakietowa, stworzona wokół firmy Bumar i lotniczo-radio-elektroniczna, stworzona wokół Agencji Rozwoju Przemysłu (ARP).

W skład Grupy Bumar wchodzą następujące firmy (oczywiście oprócz Bumaru): CNPEP Radwar S.A., Zakład Produkcji Specjalnej Sp. z o.o., Fabryka Broni Radom Sp. z o.o., WSK PZL Warszawa II S.A., ZM Dezamet S.A., Cenrex Sp. z o.o., PSP Maskpol S.A., ZM Tarnów S.A., ZM Kraśnik Sp. z o.o., Przemysłowe Centrum Optyki S.A., ZCh NitroChem S.A., ZM Mesko S.A., TM Pressta S.A., ZM Bumar-Łabędy S.A., ZM PZL-Wola S.A. W skład Grupy ARP wchodzą: WSK PZL Świdnik S.A., Polskie Zakłady Lotnicze Sp. z o.o., Kombinat PZL-Hydral S.A., Zakłady Radiowe Radmor S.A., PHZ Cenzin Sp. z o.o. [Informacja... 2004]. Oprócz wymienionych wcześniej grup istnieje, w zasadzie, jeszcze trzecia. Jest to Huta Stalowa Wola (HSW). Funkcjonuje około 20 spółek podporządkowanych HSW, zatrudniających ponad 12 tysięcy osób, a produkujących na potrzeby branży zbrojeniowej, budowlanej i stoczniowej.

Obecnie, Ministerstwo Gospodarki przygotowuje nowelizację strategii rozwoju przemysłowego potencjału obronnego. W przygotowywanych dokumentach mają być uwzględnione również niektóre firmy prywatne. Trwają też starania samorządu gospodarczego do włączenia niektórych firm prywatnych na listę firm o znaczeniu strategicznym dla bezpieczeństwa państwa. Przygotowywanie kolejnej nowelizacji strategii może świadczyć o tym, że jej realizacja zakończyła się porażką. Należy mieć nadzieję, że nie stanie się tak z jej nowelizacją.

$$
* * *
$$

Po upadku systemu komunistycznego, zakończeniu „zimnej wojny”, rozwiązaniu Układu Warszawskiego, RWPG i odejściu od gospodarki centralnie planowanej do rynkowej, okazało się, że polski przemysł obronny jest za mało konkurencyjny na kurczącym się światowym rynku broni.

Jednak większość kolejnych programów restrukturyzacji kończyła się fiaskiem. Podstawowymi powodami tego były:

- brak dobrej koordynacji pomiędzy poszczególnymi ministerstwami w kwestii realizacji programów,

- niezapewnienie odpowiedniego finansowania restrukturyzacji,

- brak konsekwencji przy realizacji programów,

- nieskuteczna kontrola wydatkowania środków pieniężnych przekazywanych przez Skarb Państwa zakładom znajdującym się w trudnej sytuacji,

- za małe nakłady na badania nad nowym sprzętem, którego sprzedaż pozwoliłaby zdobyć dodatkowe fundusze. 
Nie znaczy to jednak, że nie zachodziły również zjawiska pozytywne. Do takich można zaliczyć częściową redukcję przerostu zatrudnienia w zakładach zbrojeniowych. Kolejnym plusem było utworzenie grup kapitałowych, które mają większe możliwości zdobywania funduszy, nowych kontraktów (większa siła przebicia), mogą lepiej koordynować współpracę pomiędzy zakładami. Oczywiście na trudności zbrojeniówki miały wpływ również czynniki zewnętrzne, takie jak:

- spadek zamówień zaraz po zakończeniu ,zimnej wojny”,

- pojawienie się na rynku bardzo taniego (lub nawet darmowego) sprzętu wskutek redukcji ilości posiadanego przez państwa sprzętu powyżej pułapów przyjętych w traktacie o redukcji zbrojeń konwencjonalnych w Europie (CFE),

- wzrost konkurencji na kurczącym się rynku,

- kwestie royalities dla rosyjskich firm, które udzieliły Polsce licencji jeszcze przed 1989 rokiem.

Trzeba nadmienić, że firmy prywatne znajdują się w innej sytuacji niż państwowe. Nie mogą liczyć na wsparcie państwa, a zatem muszą bazować na umiejętnościach swoich menadżerów i pracowników, a także prowadzić badania nad nowymi produktami, być elastyczne, mieć skuteczny marketing. Część z firm prywatnych radzi sobie bardzo dobrze, nie tylko na rynku polskim, ale także za granicą.

Należy się zastanowić, co trzeba zrobić, aby polski przemysł zbrojeniowy był w stanie sprostać konkurencji na światowym rynku, a także, aby kolejne programy restrukturyzacji mogły zakończyć się sukcesem. Tu kluczowe są następujące kwestie:

1. Koncentracja produkcji ,S”.

2. Konwersja produkcji „S” na „C” (cywilna), tak aby w przypadku części zakładów przestawić je całkowicie na produkcję „C".

3. Przekazanie całej zbrojeniówki pod nadzór jednego ministerstwa. Aby było to łatwiejsze, należy zrealizować dwa wcześniejsze punkty.

4. Zapewnienie odpowiedniego finansowania realizacji następnych programów.

5. Dobry system finansowania badań nad nowymi rodzajami uzbrojenia i sprzętu wojskowego.

6. Włączanie się polskich firm w międzynarodowe programy badawcze.

7. Dogodne warunki kredytowania produkcji „S” i jej eksportu.

8. Aktywna promocja produktów polskiej zbrojeniówki (również firm prywatnych) za granicą przez administrację rządową, włączając w to przedstawicieli rządu, parlamentu, pracowników poszczególnych ministerstw, ambasady, attachaty wojskowe, wydziały ekonomiczno-handlowe ambasad.

9. Prywatyzacja zakładów, z których wyodrębniono produkcję „,S” i części (a może nawet całości) zbrojeniówki.

10. Powiązanie planów rozwoju zbrojeniówki z planami zakupów polskiego MON.

11. Konsekwencja w realizacji programów. Konsekwencja w kwestii planowanych przez MON zakupów.

12. Rozpoczęcie perspektywicznych programów badawczych.

13. Ograniczenie mieszania się polityków w zarządzanie i politykę kadrową firm państwowych.

14. Poprawienie prawa dotyczącego obrotu „S”. W chwili obecnej ustawa przerzuca całą odpowiedzialność na firmę (np. dokładne sprawdzenie zagranicznego partnera bez odpowiedniego aparatu wywiadowczego jest właściwie niemożliwe; można 
jedynie bazować na dostarczonych przez niego dokumentach; jednak mimo wydanego pozwolenia na eksport przez odpowiednie organy państwa, gdy okaże się, że mimo dostarczonych dokumentów transport trafił nie tu, gdzie powinien, to odpowiedzialność spada na firmę, a nie na urzędników), zdejmując ją z urzędników i organów państwowych.

15. Wykorzystanie offsetu do:

a) pozyskania nowych technologii,

b) wejścia na hermetyczne rynki broni, np. USA,

c) zdobycia nowych rynków,

d) stworzenia więzów kooperacyjnych,

e) wejścia w międzynarodowe programy badawcze,

f) pozyskania inwestycji.

Można sądzić, że jeśli powyższe postulaty zostaną spełnione, wtedy wzrośnie znaczenie polskiej zbrojeniówki na ryku światowym.

\section{Literatura}

ACDA, World Military Expeditures and Arms Transfers, 1987, Government Printing Office, Washington DC

Informacja o wynikach kontroli restrukturyzacji sektora obronnego, 2004, NIK, Warszawa

Kułakowski S. 2004, Ciernista droga. Polski przemyst obronny 1998-2002, „Polish Defence Industry” 5, PIPnROK, Warszawa

Raport PROXY, 1991

\section{Restructurisation of the Polish defence industry}

The article consists of three main parts. The first contains a short history and a description of the situation and potential of the Polish defence industry in years 1945-1990, and describes intensive development under USSR supervision, growing of employment, and dependency between the socialist countries' defence industries. Signals of approaching troubles started to appear already at the end of 1980s. The main signs of incoming troubles were: overgrowth of employment, not introducing any significant new technologies, and the end of the times when the sales for almost $100 \%$ of the "S" (special) production were secured.

The second part is a list of attempts at some reforms of the state-owned defence industry. The article lists trials of introducing the following restructurisation plans:

- a sector study and general assumptions for the first stage of defence industry restructurisation - Proxy Ltd., 1991

- a draft of reconstruction of the defence industry - Ministry of Industry and Trade, $1991 / 1992$

- a programme of consolidation and clearing of the defence industry companies of the debts - Ministry of Industry and Trade, 1993

- a programme of restructurisation of the defence industry and support for technical modernisation of the Armed Forces - Council of Ministers, 1999

- a strategy of the defence industry potential structural restructurisation in years 2002-2005 - Council of Ministers, 2002. 
This section of the article presents programmes description, goals, sources of financing, stages of realisation and the reasons why these programmes weren't introduced. The majority of the information in this part of the article bases on the Supreme Chamber of Control report on restructurisation of the Polish defence industry.

The third part contains conclusions and the discussion of what, according to the author, was a success, a failure and, most of all, what should be done in the future to make the state-owned (and not only) part of the Polish defence industry more modern and competitive on the world defence market. 